\title{
RENEGOTIATION AND FEDERAL TAXATION
}

\author{
WADSWORTH WATTS*
}

I

The solution of the problems arising in coordinating renegotiation with the Internal Revenue Code has been accomplished through a process of development. As originally enacted, the renegotiation statute ${ }^{1}$ which became effective April 28, 1942, did not state expressly the effect of the elimination of excessive profits upon income for the taxable year affected. The Statute, however, provided that, although the purpose of renegotiation was to eliminate excessive profits, nevertheless, this purpose was to be achieved through revision of price by renegotiation. ${ }^{2}$ At the outset, the situation was clear where excessive profits were eliminated through price reductions upon future deliveries or future performance. It also seemed clear that even though excessive profits were eliminated by retroactive price reductions resulting in a refund, if the obligation to make the refund was fixed or if the refund was paid within the taxable year in which the delivery or performance took place, then income for that taxable year was reduced. ${ }^{3}$

If, however, the renegotiation took place after the fiscal year of the contractor in which delivery or performance took place and for which year the Federal income and excess profits tax returns had been filed, questions arose concerning the taxable year in which the adjustment should be reflected. It was puzzling, too, whether the answer to this question would vary, depending upon a number of circumstances. Some of those circumstances were whether the contract had been entered into prior to the effective date of the Act, whether the deliveries with respect to which the prices were retroactively reduced had been made prior to that date, and whether the contract contained a renegotiation clause inserted pursuant to the directions contained in subsection (b) of the Renegotiation Statute. If it were determined that the retroactive price adjustment affected income for a prior fiscal year, for which a Federal tax return had been filed, must the contractor make his renegotiation refund in full through the renegotiation agency and file a claim for a refund with the Bureau of Internal Revenue, or should the Federal taxes paid with respect

\footnotetext{
*A.B. 1921, Univ. of Illinois; LL.B. I923, Columbia Univ.; Lieutenant Colonel, Army of the United States; Assistant Counsel of the War Department, Price Adjustment Board; Member of the Illinois Bar.

${ }_{5} 5$ STAT. 245, 4I U. S. C. A. note prec. \$I (Supp. r942) (Section 403 of the Sixth Supplemental National Defense Appropriation Act, I942, as amended).

${ }^{2} I d$. at $\S_{403}(\mathrm{c})$.

3 Through this article, discussion is confined to taxpayers on an accrual basis.
} 
to the excessive profits eliminated be deemed as a partial refund of the excessive profits?

Early in the administration of the Renegotiation Statute, the Bureau of Internal Revenue in a statement of policy, contained in $1 . T .3577$ (Internal Revenue Bulletin 1942, No. 37), ${ }^{4}$ gave its answer to these and other problems. The Bureau took the position that in case the renegotiation agreement provided a reduced contract price to be retroactively applied to a prior taxable year for which a tax return had been filed, and for which the income and excess profits taxes had been paid or assessed, then only the amount of the resulting refund of excessive profits which exceeded the Federal taxes assessed thereon should as a result of renegotiation be paid by the contractor. The amount of the taxes paid should be credited against the excessive profits eliminated and no refund or abatement of the taxes paid or assessed for the prior taxable year would be made. The Bureau stated, however, that in the case of a renegotiation agreement affecting a year for which income and excess profits tax returns had not been filed, the returns for that year should, when filed, reflect the results of renegotiation.

In its earliest detailed public release on policies and procedures to be followed in renegotiation, the War Department Price Adjustment Board coordinated its administration of the Act with the statement of policy expressed by the Bureau of Internal Revenue in I. T. 3577. In paragraph 4 of subdivision VIII of Principles, Policies and Procedures to be Followed in Renegotiation issued by the War Department Price Adjustment Board, dated August 10, 1942, it was stated that in renegotiation for a prior fiscal year where the return of excessive profits ordinarily takes the form of a refund, that part of the taxes previously assessed representing taxes on the excessive profits agreed upon should be taken into consideration in the renegotiation.

The Revenue Act of 1942,5 effective October 21, 1942, added Section 3806 to the Internal Revenue Code. This Section, in general, carried into statutory enactment the policies adopted by the Bureau of Internal Revenue and the War Department Price Adjustment Board with respect to the treatment of Federal income and excess profits taxes in renegotiation. The advantages of clarification by legislation of the questions involved, rather than by administrative interpretation, are obvious.

\section{II}

In conformity with well-established precedents relating to the drafting of tax legislation, the phraseology of Section 3806 is disturbingly complex. The broad aspects of the Section, however, seem clear enough. Subsection (a) provides that if, pursuant to renegotiation, excessive profits received or accrued under a contract for a prior taxable year are eliminated, and the taxpayer is required to repay such excessive profits, then the part of the contract price received or accrued for the prior taxable year is to be reduced by the amount of the repayment. Subsection (a) further provides that such repayment will not constitute a deduction for the year

4 rg42-2 CuM. BuLl. I63.

56 STAT. 798, 26 U. S. C. A. $\$ 3806$ (Supp. I942). 
in which it is paid or in which the obligation to pay it is incurred. Subsection (b), in general, states that there shall be credited against the repayment of excessive profits in such a situation the amount by which the tax for the prior taxable year would have been reduced if the excessive profits eliminated had never been a part of income. No interest, however, is to be allowed with respect to any credit to which the contractor is entitled under the Section. In subsection (c) it is stated that the credit provided under Section 3806 is to be in lieu of any other credit or refund resulting from the adjustment to income for the prior fiscal year provided for in subsection (a). And, finally, subsection (c) provides that if for any reason the credit allowable under Section $3^{806}$ exceeds that actually allowed by the renegotiation agencies against the excessive profits eliminated, then such excess is to be treated as an overpayment of tax for the prior taxable year.

While Section 3806 of the Internal Revenue Code clarified the most important questions involved in the correlation of taxes and renegotiation, nevertheless, in its application to renegotiation, some questions have arisen.

Effect of Retroactive Price Reductions on Post-war Refund of Excess Profits Tax. By Section 780 of the Internal Revenue Code, the Secretary of the Treasury is directed to establish a credit for the account of each taxpayer subject to the excess profits tax, of an amount equal to $10 \%$ of the excess profits tax for each taxable year ending after December 3I, I94x. This credit is to be realized by the taxpayer after the war. When a credit is granted under Section 3806 of the Internal Revenue Code, is this post-war refund credit reduced? A strange situation would result were it not reduced. The corporation which currently priced its war products at figures yielding only reasonable profits would, of course, pay no excess profits tax on any excessive profits since none ever accrued in its income. But the corporation which priced its products to yield excessive profits, resisted all efforts on the part of procurement officials to price reasonably and delayed renegotiation until after filing its tax returns, would receive a bonus equal to $10 \%$ of the excess profits tax paid upon its excessive profits. And the higher the price the larger in dollars would be this bonus. Fortunately, it seems quite clear that such a situation does not exist. While the credit under Section 3806 is granted and allowed by the renegotiation agencies, not the Bureau of Internal Revenue, nevertheless, it is a credit granted pursuant to the Internal Revenue Code, since Section 3806 is a part of that code. Section $78 \mathrm{r}(\mathrm{b})$ of the Code provides that if any overpayment of the tax imposed by Chapter $2 \mathrm{E}$, the chapter imposing the excess profits tax, is refunded or credited to the taxpayer under the internal revenue laws, the post-war credit shall be reduced accordingly. The Section 3806 credit is clearly a credit under the internal revenue laws. Also, it would seem to be a credit of an overpayment of the excess profits tax. The basic theory of Section 3806 is that the taxpayer overpaid its tax through being taxed on profits which in effect it was not entitled to retain and must refund. The simple way of adjusting for the overpayment is the method provided in the section. The result to the taxpayer and to the United States is exactly the same in dollars, as though the taxpayer had refunded its excessive profits in full without tax 
credit, had amended its return for the year affected by the retroactive price reduction, and had claimed a refund resulting from an overpayment of the tax for that year.

That the post-war refund is adjusted to reflect a credit granted by a renegotiation agency is pointed out by the Bureau of Internal Revenue in $I . T .36 r .^{\circ}$ In that interpretation of Section 3806 the Bureau states:

"In view of the provisions of Section 3806 , it is the opinion of this office that the taxpayer's net income for Federal income and excess profits tax purposes is required to be in effect, determined upon the basis of, and by giving effect to the renegotiation *** Also the amount of the post-war refund under Sections 780 and $78 \mathrm{r}$ of the Code of excess profits tax shall be reduced to reflect the amount of such tax which is credited against the excessive profits eliminated."

Effect of a tax credit under Section 3806 upon income for tax purposes for the prior year. $A$ has net income for tax purposes in 1943 of $\$ 2,000,000$. After he has filed his r943 return he is renegotiated for that year and agrees to refund $\$ 750,000$. His Section 3806 tax credit is computed and appears to be $\$ 600,000$ based upon the return as filed, and he pays through the renegotiation agency $\$ 150,000$, the net amount remaining after the application of the credit. When, however, the Bureau of Internal Revenue audits $A^{\prime} s$ return, it finds that his net income for tax purposes was $\$ 500,000$ in excess of that shown by the return. Will the Bureau compute the deficiency upon the basis of an income of $\$ 1,750,000$, the income shown by the return as filed but adjusted for renegotiation plus the additional $\$ 500,000$, or upon an income of $\$ 2,500,000$, the income shown by the return as filed but unadjusted for renegotiation and plus the additional \$500,000? This, of course, is important to an individual in view of the graduated nature of the Federal tax.

It is clear from the provisions of Section 3806 (a) (I) that, although the tax return for the prior year has been filed and the tax assessed, a retroactive price reduction for the prior year effected through renegotiation reduces income for that prior year. Therefore, in $A^{\prime} s$ case the deficiency in tax must be computed upon an income of $\$ 1,750,000$, the income adjusted for the renegotiation refund and plus the additional $\$ 500,000$. Nor is it necessary to amend the tax return for the prior year to effect this result. Section 3806 indicates that the adjustment to income is automatic, and the Bureau of Internal Revenue is requiring no amended return in order to effect the adjustment. In $I . T .36 r r^{7}$ the Bureau states:

"In view of the provisions of Section 3806 it is the opinion of this office that the taxpayer's net income for Federal income and excess profits tax purposes is required to be in effect determined upon the basis of, and by giving effect to, the renegotiation." (Emphasis supplied.)

Effect of the Granting of a Section 3806 Tax Credit Upon Subsequent Tax Refunds. Corporation $B$ had a net income for Federal tax purposes for 1942 amounting to $\$ 3,000,000$. It has filed its Federal tax returns for that year and a tax of $\$ 2,400,000$ has been paid or assessed with respect to 1942 income. It is re-

\footnotetext{
- I943 INT. Rev. Bull. No. 12, at 7, 8.
}

${ }^{\top}$ Ibid. 
negotiated for 1942 after its returns have been filed and agrees to refund $\$ 2,000,000$ as excessive profits. The Section 3806 tax credit relating to this refund is $\$ 1,600,000$ resulting in a net cash refund through the renegotiating agency of $\$ 400,000$. In a fiscal year ending after the termination of the war it loses $\$ 1,500,000$ which pursuant to the provisions of the Internal Revenue Code may be carried back to the year 1942, resulting in an adjustment of the income and excess profits tax for the year 1942 and a tax refund resulting from this adjustment. Is the tax available for refund the $\$ 2,400,000$ shown upon the returns as filed, or is it this amount reduced by the credit allowed pursuant to the provisions of Section 3806? A similar problem would arise had Corporation $B$ been entitled to an adjustment of the income and excessive profits tax for I942 through accelerated amortization of emergency facilities with respect to which certificates of necessity had been issued. The tax available for refund is not the $\$ 2,400,000$ shown upon the returns filed, but is the amount reduced by the $\$ 1,600,000$ used as a credit against the 1942 excessive profits eliminated. While the only specific provision of Section 3806 of the Code relating to other credits or refunds is that contained in subsection (c) of that section which provides against other credits or refunds under the internal revenue laws founded on the application of subsection (a) of Section 3806; nevertheless, in view of the fact that Section 3806 (a) specifically provides that a retroactive price reduction reduces income for the prior year, it would seem to follow necessarily that the tax for the prior year is reduced to the extent of a tax credit granted. The Bureau of Internal Revenue in $I . T .3^{6 r r^{8}}$ states its position that "no refund of tax for any taxable year shall include any amount of tax which, pursuant to Section $3806(\mathrm{~b})$ is credited against excessive profits eliminated for such year." An example is given in $I . T .36 r I^{9}$ of a corporation receiving a $\$ 700,000$ tax credit under Section $3^{806}$ and the Bureau states with respect to this $\$ 700,000$ that "no part of the $\$ 700,000$ Federal income and excessive profits taxes shall be refunded or credited to the taxpayer under Sections 321 and 322 of the Code. However, for the purpose of determining the correct tax for I942 the amount of tax shown by A Corporation on its return for such year shall be decreased by the $\$ 700,000$ credit allowed against excessive profits."

Declared Value Excess Profits Tax. It will be observed that Section 3806(b) of the Internal Revenue Code provides for credit against excessive profits eliminated of the amount by which the tax for the prior taxable year under Chapter I, Chapter $2 \mathrm{~A}$, Chapter $2 \mathrm{D}$ and Chapter $2 \mathrm{E}$ of the Internal Revenue Code is decreased by reason of eliminating from income the excessive profits agreed to be refunded. Chapters $\mathrm{I}, 2 \mathrm{~A}$ and $2 \mathrm{D}$ relate to income taxes. Chapter $2 \mathrm{E}$ relates to the excess profits tax. Chapter $2 \mathrm{~B}$ relating to the declared value excess profits tax is conspicuous by its absence. Nevertheless, it will be seen from an example set forth in I. T. $3^{6}{ }_{1 I^{10}}$ that in computing Section $3^{806}$ tax credits, the computation includes a credit to the extent by which the declared value excess profits tax for the prior year is reduced through the adjustment to income resulting from renegotiation. Al${ }^{8}$ Ibid.

${ }^{\circ}$ Id. at 9 .

${ }^{20}$ Ibid. 
though Chapter $2 B$ is not specifically mentioned in Section $3806(\mathrm{~b})$, it must be remembered that Section 3806(a) requires an adjustment of income for the prior year to reflect a retroactive price reduction effected through renegotiation. Were Chapter 2B not considered in computing the Section 3806 credit, it would seem that the Bureau would be required to adjust the declared value excess profits tax through some sort of an amendment to the return for the prior year. Since the purpose of Section 3806 seems to have been to effect all necessary adjustments in the tax resulting from required adjustments to income caused by retroactive price reductions, the reasonable interpretation of the Section seems to be that the declared value excess profits tax adjustment should be made through the Section 3806 credit. At any rate it is the position of the Bureau of Internal Revenue that a Chapter $2 B$ adjustment should be allowed and it is included in their computations in the amount of the credit. (See $I$. T. 36 II cited above.) ${ }^{10^{2}}$

Necessity of Coordination between Renegotiating Agencies and the Bureau of Internal Revenue. As pointed out above, while Section 3806 is a part of the Internal Revenue Code, nevertheless, the credit based upon that section is actually allowed by the renegotiation agencies. In practice, the Internal Revenue Agent in Charge of the district in which the contractor has filed his tax return is asked to compute the amount of credit to which the contractor is entitled, based upon his tax return as filed. The original of this computation is sent to the renegotiation agency with a copy to the contractor. The mere fact that an Internal Revenue Agent in Charge has.been asked to make a computation is not a sufficient basis for the Bureau of Internal Revenue to make the required adjustments to income. The computation of credit may be asked in contemplation of an agreement to be made in the future and for some reason or other the transaction may not be carried through, in which event no credit would be allowed. Therefore, when a renegotiation agreement is signed and an allowance of a tax credit against excessive profits eliminated is actually made by a renegotiation agency, the Bureau of Internal Revenue is notified. The Bureau then has in the taxpayer's file sufficient information to effect the necessary adjustments, no matter what they may be, or when they may arise.

Effect of Section 3806 on I. T. 3577.11 It will be recalled that $I . T .3577$ mentioned above was issued by the Bureau of Internal Revenue prior to the enactment of Section 3806 of the Code. While Section 3806 codifies that portion of $I . T .3577$ relating to renegotiation for a prior fiscal year following the filing of the tax returns for that year, nevertheless, it is not explicit as to the effect of the elimination of excessive profits by retroactive price reductions effected before the tax returns have been filed. Upon the enactment of Section 3806 of the Code, question was raised as to whether in view of this situation $I$. T. 3577 still expressed the policy of the Bureau with respect to retroactive price reductions made by refunds or agreements to re-

\footnotetext{
${ }^{10 a}$ Section $70 I(c)(2)$ of the Senate Finance Committee's version of the Revenue Bill of r943 (H. R. 3687 , 78th Cong., Ist Sess., 1943) includes an amendment to Section 3806 (b)(I) and (b) (2) of the Internal Revenue Code which would make these subsections explicit in directing that the declared value excess profits tax be considered in determining tax credits under Section 3806.

11 Supra note 4.
} 
fund prior to the filing of the tax return for the year affected. These questions have been answered by $I$. $T$. $3^{6} I I^{12}$ which reaffirms the statement of policy continued in $1 . T$. 3577 relating to retroactive price reductions effected before the returns for the year affected have been filed.

It should be pointed out that one qualification exists to the general proposition that if a taxpayer agrees to repay excessive profits prior to the filing of a Federal tax return for the year affected, the excessive profits agreed to be repaid should be and are eliminated from income in the returns filed for that year. If at the time the Bureau audits the taxpayer's return for the year affected, the taxpayer is in default in any payments required to be made under his renegotiation agreement and which have been eliminated from income in preparing the return, the Bureau will add these defaulted payments to income for the year, and collect the tax with respect thereto. For example, Corporation $A$ having income of $\$ 2,500,000$ for the year I942, is renegotiated before its returns for that year are filed, and agrees to repay $\$ 1,000,000$ in excessive profits. This it agrees to pay in four equal installments, one on March 15, 1943, another on June 15, I943, still another on September I5, I943, and the last on December 3I, r943. In accordance with $1 . T$. 3577 the entire $\$ 1,000,000$ is then eliminated from income in filing its returns on March ${ }^{5}$, I943. The Bureau then audits its returns early in 1944 and finds the corporation has not paid the last two installments aggregating $\$ 500,000$. The Bureau will add these defaulted installments to 1942 income and assess a deficiency tax with respect thereto.

The taxpayer will immediately be concerned whether, after this deficiency has been assessed, he will then be liable for these two installments in full under his renegotiation agreement. The standard form of agreement now in use by the renegotiation agencies, contains substantially the following clause, although the renegotiation relates to a year for which tax returns have not been filed:

"Should for any reason the profits eliminated hereby be includable in gross income of the contractor for the purposes of determining taxes payable for said fiscal year under Chapters $I, 2 A, 2 B, 2 D$ and $2 E$ of the Internal Revenue Code the contractor shall be allowed the credit, if any, to which he is entitled under Section $3^{806}$ of the Internal Revenue Code with respect to the profits eliminated hereby."

It is intended by this clause to make it clear that if for any reason such taxes are assessed by the Bureau upon any of the profits eliminated, the contractor will be entitled to the appropriate credit in refunding such profits through a renegotiating. agency.

\section{III}

When the Current Tax Payment Act of $1943^{13}$ became effective, question immediately arose as to its effect upon Section $3^{806}$ of the Internal Revenue Code. The Current Tax Payment Act of I943 provides that the income tax of each individual for the taxable year 1942 is forgiven as of September I, I943. While the tax for the

${ }^{12}$ Supra note 6.

${ }^{13}$ Pub. L. No. 68, 78 th Cong., Ist Sess. (June 9, I943); 57 Stat. - 
taxable year 1943 under this act is based to an extent upon income for the taxable year 1942, nevertheless, the tax assessed is for the 1943 taxable year and not for the I942 taxable year. If the income for the taxable year 1942 is greater than the income for the taxable year 1943, then the I943 tax is substantially the tax, computed at the rates provided in the Internal Revenue Code, on the income for the taxable year 1942, plus $25 \%$ of the tax based on the income for the taxable year 1943 similarly computed. On the other hand, if the income for the taxable year 1942 is not greater than the income for the taxable year 1943, then the tax for 1943 is in substance the tax on the income for the 1943 taxable year, computed at the rates provided in the Internal Revenue Code, plus $25 \%$ of the tax on the income for the 1942 taxable year similarly computed. All payments made on account of the 1942 assessment, now forgiven, are applied on account of the 1943 assessment. The $25 \%$ of the tax computed upon income for the lesser income year may be deferred one-half until March 15, r944 and the other half until March 15, 1945. There are, of course, provisions in the Current Tax Payment Act relating to a windfall tax, but for the purposes of the discussion here these provisions are not considered.

In view of the fact that the tax for the year $1942^{14}$ is forgiven it would seem clear that where an individual is renegotiated for the year 1942, agreeing to make retroactive price reductions through a refund, he is entitled to no tax credit under Section $3^{806}$. On the other hand, it would seem, too, that to the extent that his I943 tax is based upon income for the year 1942, the individual taxpayer should receive all benefits taxwise of the adjustment to income effected through renegotiation. After a consideration of the matter the Bureau of Internal Revenue issued I. T. $36 \mathrm{rg}{ }^{15}$ In substance $I$. T. 3619 provides (a) that where retroactive price reductions made pursuant to renegotiation by an individual affect the year 1942, that individual is entitled to no tax credit under Section 3806 of the Internal Revenue Code, since the liability of the individual for the tax for the year 1942 becomes discharged as of September I, I943 and since the payments on account of such tax are considered as payments on account of the tax for the taxable year 1943; and (b) that the taxpayer, however, in estimating his tax for 1943 at September 15, 1943, and December 15, 1943, and in filing his 1943 return on March 15, 1944, may eliminate from I942 income the excessive profits refunded or agreed to be refunded.

The Current Tax Payment Act of 1943 and I. T. 3619 has caused consideration of two principal questions by the individual contractor who is renegotiated for 1942. The first question is whether in the long run, since he will receive no Sec. tion 3806 credit against excessive profits eliminated, he will be required to repay more dollars in renegotiation refunds and taxes than he would have had to pay had the Current Tax Payment Act not been passed? The second question is, must these dollars in taxes and renegotiation be paid earlier than if the Current Tax Payment Act had not been passed, i.e., how have the demands upon working capital been affected?

\footnotetext{
14 Hereafter when a year is referred to the reference is intended to be to a taxable year as defined in the Current Tax Payment Act of 1943.

${ }^{15}$ I943 INT. REv. BuLL. No. 16, at 6-7.
} 
No doubt, at this point, the situation appears very complex. By using examples, however, the situation may perhaps be simplified. For example, let us consider individual Contractor $A$ with respect to whom the following facts exist:

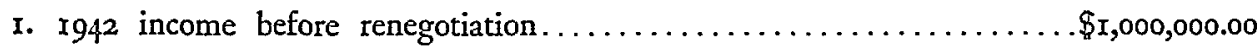

2. 1942 tax computed before passage of the Current Tax Payment Act.... 855, 140.00

3. r942 excessive profits to be refunded pursuant to renegotiation, all of

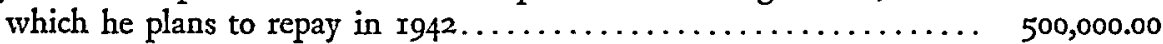

4. Taxes computed upon 1942 income adjusted to reflect renegotiation.... 415, I40.00

5. The tax credit to which he would have been entitled under Section 3806

had the Current Tax Payment Act not been passed........... 440,000.00

6. Income during each of the years 1943 and $x 944 \ldots \ldots \ldots \ldots \ldots \ldots 2,000,000.00$

7. Tax at present rates for each of the years 1943 and $1944 \ldots \ldots \ldots \ldots$ I,795, I40.00

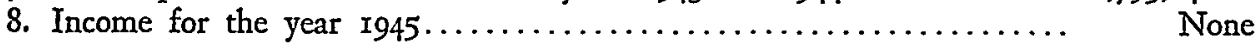

It will be seen that the income of Contractor $A$ for the year I942 after renegotiation is not greater than his income for the year I943. Therefore, his tax for the year I943 is equal to the tax computed upon I943 income plus $25 \%$ of the tax computed on 1942 income. The tax computed on his r943 income is $\$ 1,795,140$. The tax computed on his 1942 income adjusted to reflect renegotiation is $\$ 415,140,25 \%$ of which will become a part of the 1942 tax. This $25 \%$, namely, $\$ 103,785$, is payable one-half on March 15, I944, and one-half on March 15, r945. Therefore, his I943 tax is $\$ I, 898,925$, of which $\$ I, 795, \mathrm{I} 40$ is payable in I943, $\$ 5 \mathrm{I}, 893$ is payable in $\mathrm{I} 944$, and $\$ 51,893$ is payable in 1945 . Contractor $A^{\prime}$ s situation before and after the passage of the Current Tax Payment Act based upon the assumptions above set forth appears as follows:

Cash requirements in renegotiation refunds and taxes of Contractor $A$ in the years 1943,1944 and 1945 before and after the passage of the Current Tax Payment Act of $1943^{16}$

\section{Had the Act Not Been Passed}

$1943 \quad 1944$

1945

Federal Taxes ............... \$ 855, 140

Excessive profits refunded for 1942 after application of the Section 3806 tax credit ............ 60,000

Total taxes and renegotiation refunds

$\$ 915,140 \quad \$ 1,795,140 \$ 11,795,140^{17}$

\section{After Passage of the Act}

Federal Taxes $. \ldots \ldots \ldots \ldots \ldots \ldots \ldots 1,795,140$

Excessive profits refunded for $1942-$

no Section 3806 credit ........ 500,000

Total taxes and renegotiated refunds

$\$ 2,295$, I $40 \quad \$ 1,847,032 \$ 5 \mathrm{I}, 893^{18}$

From a study of these figures it can be seen that if $A$ pays his entire excessive profits refund for $\mathrm{I} 942$ in $\mathrm{I} 943$ his cash requirements for the latter year have been

${ }^{18}$ No consideration is given to any renegotiation for 1943 or 1944 .

${ }^{27}$ Taxes on $\mathrm{x} 944$ income.

${ }^{18}$ One-half of that part of the 1943 tax based on $I 942$ income. The other half is in the $\$ 1,847,032$ figure in the r944 column. 
heavily increased compared to what would have been his cash requirements for that year had the Current Tax Payment Act not been passed. These requirements are $\$ 2,295,140$ after the Act, compared with $\$ 915,140$ had the Act not been passed. In order to aid a contractor in this situation the War Department Price Adjustment Board has adopted a policy of allowing the I942 renegotiation refund to be deferred through the year I944 if his current position requires it. It can be seen, however, that Contractor A's cash requirements in I944 continue to be heavy. But this policy gives the contractor time to plan for these cash requirements, and the renegotiation agencies are limited in extending time by the fact that the tax effects described in $I . T .3^{6} \mathrm{Ig}$ seem to be effective only if "the taxpayer before the close of the taxable year following the taxable year 2943 pays to the United States the entire amount of the excessive profits determined by a renegotiation for the taxable year 1942. ***" (Emphasis supplied.) ${ }^{19}$

It will also be observed from the total payments required by Contractor $A$ in the three years set forth in the foregoing schedule that after the Current Tax Payment Act, he will have paid less in renegotiation and taxes than he would have paid had that Act not been passed. It may be thought that this comparison is without significance since no income has been assumed for Contractor $A$ in 1945 . To compare the situations of a taxpayer before and after the Current Tax Payment Act the figures must be carried either to the year of his death or to a year with little or no income, one of which events, needless to add, is certain to occur. In any case, however, if the figures of a contractor in $A$ 's income situation for 1942 and 1943 are carried until the occurrence of either of these events, the total paid in taxes and renegotiation after the Act will not exceed those required had the Act not been passed.

Had the Current Tax Payment Act not been passed, Contractor A would have received a Section 3806 tax credit, equal to the taxes assessed for 1942 on the excessive profits eliminated. Since the passage of the Act a similar benefit is derived through the elimination of these excessive profits from 1942 income in computing the 1943 tax. In the case of Contractor $A$ this benefit is limited, however, since only $25 \%$ of the tax computed on 1942 income becomes part of the 1943 tax. This, of course, accounts for his heavy cash requirements in 1943. On the other hand, if excessive profits are eliminated for 1943, his Section 3806 tax credit will be equal to the entire tax assessed upon the excessive profits eliminated for 1943, since included in the 1943 tax is $100 \%$ of the tax computed on 1943 income.

Contractor $B$ finds himself in the following situation:

r. $x 942$ income before renegotiation........................ \$2,000,000.00

2. I942 tax computed before passage of the Current Tax Payment Act.... I,735, I40.00

3. I942 excessive profits to be refunded pursuant to renegotiation, all of

which he plans to repay in $1943 \ldots \ldots \ldots \ldots \ldots \ldots \ldots \ldots \ldots \ldots \ldots \ldots \ldots \ldots \ldots, 000,000.00$

4. Tax computed upon 1942 income adjusted to reflect renegotiation...... $855,140.00$

5. The tax credit to which he would have been entitled under Section 3806 had the Current Tax Payment Act not been passed............. 880,000.00 ${ }^{10}$ I. T. ${ }_{3619,} 1943$ INr. Rev. BuLx. No. 16, at 6, 7. 
6. Income during the years 1943 and 1944 , respectively

7. Tax computed upon income for each of the years 1943 and $r 944 \ldots \ldots$.

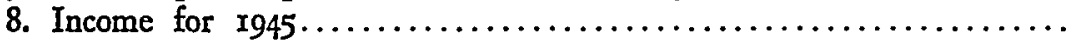

None

The 1942 income of Contractor $B$ after renegotiation is greater than his 1943 income. Therefore, his tax for the year 1943 is equal to the tax based upon I942 income, plus $25 \%$ of the tax based upon 1943 income. Contractor B's situation, had the Current Tax Payment Act not been passed, and after its passage based upon the assumptions above set forth, is as follows:

Cash requirements in renegotiation refunds and taxes of Contractor $B$ in the years 1943, 1944 and $1945^{\circ}$ before and after the passage of the

Current Tax Payment Act of $1943^{20}$

Had the Act Not Been Passed

$1943 \quad 1944 \quad .1945$

Federal Taxes .............. \$1,735,140

Excessive profits refunded for 1942 after application of Section $3^{806}$

tax credit

120,000

Total taxes and renegotiation

refunds

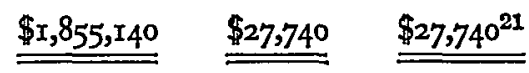

After Passage of the Act

Federal Taxes

Excessive profits refunded for $1942-$

No Section 3806 credit

$855,4^{40}$

…..... $\mathrm{r}, 000,000$

\section{$\stackrel{\$ 1,855,140}{=\$ 31,207} \stackrel{\$ 3,468^{22}}{=}$}

Unlike Contractor $A$, the cash requirements of Contractor $B$ in 1943 for renegotiation refunds and taxes are the same as though the Act had not been passed. This results from the fact that included in the 1943 tax is $100 \%$ of the tax computed upon 1942 income, and the fact that only that part of the 1943 tax is payable in I943. Since $100 \%$ of the tax computed on 1942 income is included in the 1943 tax, elimination pursuant to $I . T .36 \mathrm{rg}$ of the renegotiation refund from income for x942 results in a reduction in the I943 tax equal to the full tax on the excessive profits eliminated for 1942. Although Contractor $B$ pays his renegotiation refund in full without credit under Section 3806 , his 1943 tax is, as a result of renegotiation, reduced by an amount equal to the tax credit he would receive under Section 3806 with respect to his 1942 assessment had it not been abated by the Current Tax Payment Act. If, however, Contractor $B$ refunds excessive profits for 1943, such refunds will reduce income for the lesser of the two years involved. Therefore, the tax credit under Section 3806 in connection with the 1943 renegotiation will not be the taxes in full computed upon the excessive profits eliminated but only $25 \%$

${ }^{30}$ No consideration is given to any renegotiation for 1943 or 1944 .

31 Taxes on 1944 income.

${ }^{23}$ One-half of that part of the 1943 tax based upon 1943 income. The other half is in the $\$ 3 I, 207$ figure in the 1944 column. 
of those taxes. Here he will find himself in the same position as Contractor $A$ finds himself with respect to excessive profits eliminated from $x 942$ income.

Like Contractor $A$, the total payments of Contractor $B$ in taxes and refunds during the three year period under the conditions assumed will not exceed those he would have been required to make had the Current Tax Payment Act not been passed.

\section{IV}

By reason of the nature of the Renegotiation Statute and the Internal Revenue Code, new questions will constantly arise involving the relation of the two laws. It will appear from the discussion that has gone before that several principles seem to have governed in solving many of the questions that have already arisen. The first is that the results of renegotiation for a contractor should be substantially the same regardless of whether his renegotiation occurs before or after he has filed his Federal returns for the year affected. The second is that a contractor should not be required to pay taxes upon income refunded pursuant to renegotiation, or be required to refund pursuant to renegotiation income to the extent that he has paid taxes on such income. The third is that administratively the handling of renegotiation and taxation should be such that a contractor will not be required to pay money to one agency of the United States Government and be required to claim a refund from another such agency, based upon the payment to the first. In view of the history of the administration of the Internal Revenue Code and the Renegotiation Statute in their relation to each other it would appear that many of the future questions that may arise offer promise of being settled ultimately through application of these three principles. ${ }^{23}$

${ }^{23}$ Although the relationship of renegotiation and state taxes levied upon or measurcd by income is outside the intended scope of this article, it may be desirable to indicate briefly the nature of the general problem involved. Under Subsection (c)(3) of the Renegotiation Act state "income" taxcs are allowable costs in renegotiation to the extent applicable to renegotiable business. The fundamental question is whether the portion of the state tax attributable to the retroactive price adjustment should be allowed as a cost in renegotiation. There is no question as to the propriety of allowing as a cost the portion of the state tax attributable to the renegotiated profits not deemed excessive.

Based upon the statutory conception that the process of renegatiation is one of over-all repricing, it would seem that for state tax purposes the contractor should be treated as though he had never received the income represented by the price adjustment, that state income taxes on such portion of his income should not be allowed as a cost in renegotiation, and that if he has paid state income taxes on such portion of his income, those taxes should be refunded. Several states, however, have refused to recognize the effect of retroactive renegotiation upon the contractor's income or have given only partial recognition thereto. Analysis of the reasons offered in justification of this position seems to indicate that the basic contention of these states is that the Federal Government should permit the states to retain this portion of the contractor's excessive profits to compensate for loss by the states of other sources of revenue. Whether the states having war contractors should be given a subsidy in this form is obviously a serious question.

Pending clarification of the situation, however, the renegotiation agencies have generally allowed as an item of cost state taxes upon income unreduced by excessive profits eliminated if state taxes upon such income have been paid. The contractor, however, is required to perfect a claim for a refund of state tax based upon the elimination of excessive profits from income, and if refund is made to pay it to the United States. In this connection it is of interest to note that in the Finance Committec version of the Revenue Bill of 1943 there is a direction which would appear to require the renegotiation agencies to allow as an item of cost state income taxes only upon incomet after being adjusted for excessive profits eliminated. See $403(\mathrm{a})(4)$ (B) of the Renegotiation Statute, as proposed to be amended by Section jox(b) of the Finance Committee Bill, Revenue Bill of x943 (H. R. 3687). 